Scientific Journal Warsaw University of Life Sciences - SGGW

Problems of World Agriculture volume 19 (XXXIV), number 3, 2019: 75-84 DOI: 10.22630/PRS.2019.19.3.48

Jakub Olipra ${ }^{1}$

Warsaw School of Economics, Poland

\title{
Change in Seasonality Pattern of EU Farmgate Milk Price
}

\begin{abstract}
Since 2007 farmgate milk prices in EU have become much more volatile and their seasonal pattern has stopped being so explicit. The purpose of this research is to test the hypothesis that seasonality still plays an important role in shaping farmgate milk prices in EU while its amplitude decreases together with the growing integration of the EU milk market with the global market. The aforementioned issues are investigated using Census X-12 procedure of price decomposition and panel random effects model. The results indicate that after 2007 the role of seasonality in determining EU farmgate milk prices has significantly decreased which partially results from the higher integration of the EU milk market with the global market. Nevertheless, seasonality remains an important factor determining the farmgate milk prices in EU. It can be expected that with the further globalization of the milk market, the significance of seasonality in determining farmgate milk prices in EU will be diminishing.
\end{abstract}

Key words: farmgate milk price, seasonality, forecasting, globalization, panel regressions

JEL Classification: C500, Q110, F600

\section{Introduction}

For many years farmgate milk prices in the major European Union (EU) milk producing countries used to reveal a strong seasonal pattern oscillating around long-term trends. However, since the beginning of 2007, together with the increasing integration of EU milk market with the global milk market, the prices have become much more volatile and their seasonal pattern has stopped being so explicit (see Figure 1). Change in behavior of the farmgate milk prices has significantly lowered their predictability increasing the risk of business activity in the dairy sector as a consequence.

With regards to the biological nature of milk production, the lack of explicit seasonal pattern most likely does not mean that the influence of seasonality on farmgate milk prices has completely abated. Nevertheless, its significance in determining farmgate milk prices in EU may have changed. Aforementioned issue has not been directly addressed so far as literature focuses mainly on the biologic and microeconomic aspects of seasonality and does not cover the role of external factors like globalization. There is some research on the decomposition of farmgate milk prices, nevertheless seasonality is not its main focus. Therefore, the aim of this analysis is to test the hypothesis that seasonality still plays an important role in shaping farmgate milk prices in EU but its amplitude decreases together with the growing integration of the EU milk market with the global market. Findings from this research may be useful for representatives from the dairy sector in forecasting of farmagate milk prices.

\footnotetext{
${ }^{1}$ MA, Collegium of Economic Analysis, Warsaw School of Economics, e-mail: jakub.olipra@gmail.com; https://orcid.org/0000-0001-9216-6056
} 


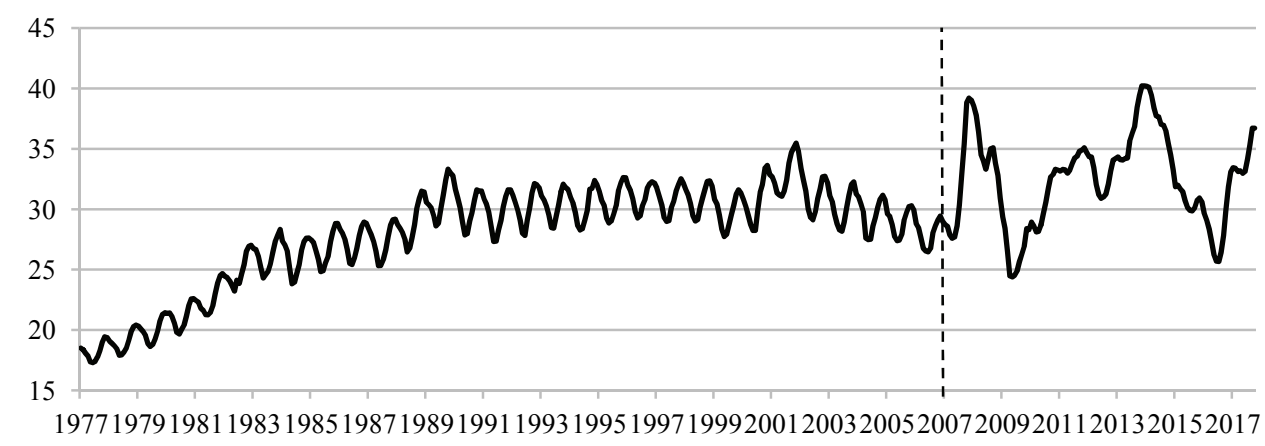

Fig. 1. EU farmgate milk price (EUR/100 kg)

Source: EU Milk Market Observatory.

The paper is organized as follows. Section 2 provides the literature review in the field of seasonality in the milk market. Section 3 describes the data collection and econometric methods employed in the research. Section 4 shows the results of the estimations. Section 5 presents concluding remarks.

\section{Literature review}

Seasonality of farmgate milk prices is a consequence of the seasonality of milk supply and changes in milk composition over the year (fat and protein content). In the Northern Hemisphere the production peak takes place in spring/summer exerting downward pressure on the prices, while the supply dip is observed in autumn/winter causing seasonal increase in prices. Moreover, in autumn/winter milk tends to contain more fat and protein which is positive for its price. According to the literature, amplitude of the seasonality is determined both by biological and economic factors which are usually highly connected. The most important ones are:

- Calvings distribution. More balanced calvings distribution leads to more stable milk supply over the year (Auldist et al., 1998; Kelly, 2001; Dooley, 2002; Matysik-Pejas, 2007; Szajner 2014). The peak of milk efficiency takes place within the first 100 days of the lactation period (Scott et al., 1996). Therefore, more balanced calving distribution over the year enables to achieve a few milk production peaks and smooth the milk output. The optimization of calvings distribution was investigated i.a. by Killen and Keane (1978), Scott et al. (1996) and Baul et al. (2014).

- Feeding regime. More balanced diet of dairy cows leads to more stable milk composition. Ruminants should receive homogenous feeding as any changes in the feeding regimes, like shifting from pasture feeding to concentrate feeding and vice versa, affect the quantity of dry matter in the milk, especially fat (Egersma et al., 2004; Burke et al., 2007; Sienkiewicz and Góralska, 2009; Nategi et al., 2014; Oldemiro et al., 2016; Hayer et al., 2019). The feeding pattern is usually 
determined by the geographical conditions like temperature and availability of pastures. Favorable geographical conditions are conducive to higher share of extensive farming and pasture-based feeding pattern which is associated with higher amplitudes of seasonality. In turn, less favorable geographical conditions are conducive to higher share of intensive farming and concentrate-based feeding pattern which is less dependent on seasonal factors.

- Size of dairy farms. According to the literature, the amplitude of supply seasonality is negatively correlated with the size of dairy farms and their specialization (Allore et al., 1997; Matyjasik-Pejas, 2007; Iwan, 2005). Due to high scale effects larger farms are able to afford for better veterinary care, more milk-efficient dairy cow species, high quality fodders, which decreases the amplitude of seasonality. Hence, it may be expected that amplitudes of seasonality will be gradually decreasing together with higher development of dairy sector.

Seasonality of farmgate milk prices was partially investigated in the research on business cycles in the milk market. Bergmann et al. $(2013,2015)$ decomposed German, Irish and EU average farmgate milk prices into trend, seasonal and cyclical components using Kalman filter. Authors divided their sample into two parts: 1990-2003 (prior to the reform of Common Agricultural Policy) and 2003-2013. With regards to the seasonality of farmgate milk prices their results indicate that in both samples the time series exhibit a seasonal pattern. Nevertheless, results shows that seasonal component in all cases is almost constant over the time. It is not consistent with the findings of Iwan (2005), Matysik-Pejas (2007) and Szajner (2014) that the amplitudes of seasonal component of milk prices tends to follow downward trend due to proceeding specialization and development of dairy sector. Nicholson and Stephenson (2015) employed the same method as Bergmann et al. $(2013,2015)$ for the US market and obtained similar results in terms of seasonality. It may suggest that State Space Models and Kalman filter are not optimal tools for deriving seasonal component from the farmgate milk prices.

\section{Methodology and data collection}

As the aim of the research is to test two hypotheses it is divided into two parts. The first part investigates if the seasonality still plays an important role in shaping the farmgate milk prices in EU. The second part tries to answer the question if the amplitude of the seasonal component in the farmgate milk prices in EU is decreasing together with the growing integration of the EU milk market with the global milk market.

EU farmgate milk prices analyzed in the first part of the research are monthly average prices of raw milk at real fat and protein content paid to milk producers nominated in EUR and obtained from the EU Milk Market Observatory. Sample includes only countries which used to reveal a strong seasonal pattern and experienced a marked change in farmgate milk price behavior after 2007. Therefore, finally data for 11 countries was included in the research: Belgium, Denmark, Germany, Ireland, France, Luxembourg, Netherlands, Austria, Finland, Sweden and the United Kingdom. The length of sample was determined by the availability of data. Nevertheless, as sample includes only countries from EU-15, in most cases it covers period from January 1977 to September 
2017. Time series used in the research are presented in Figure 2 while Table 1 reports their length and descriptive statistics.
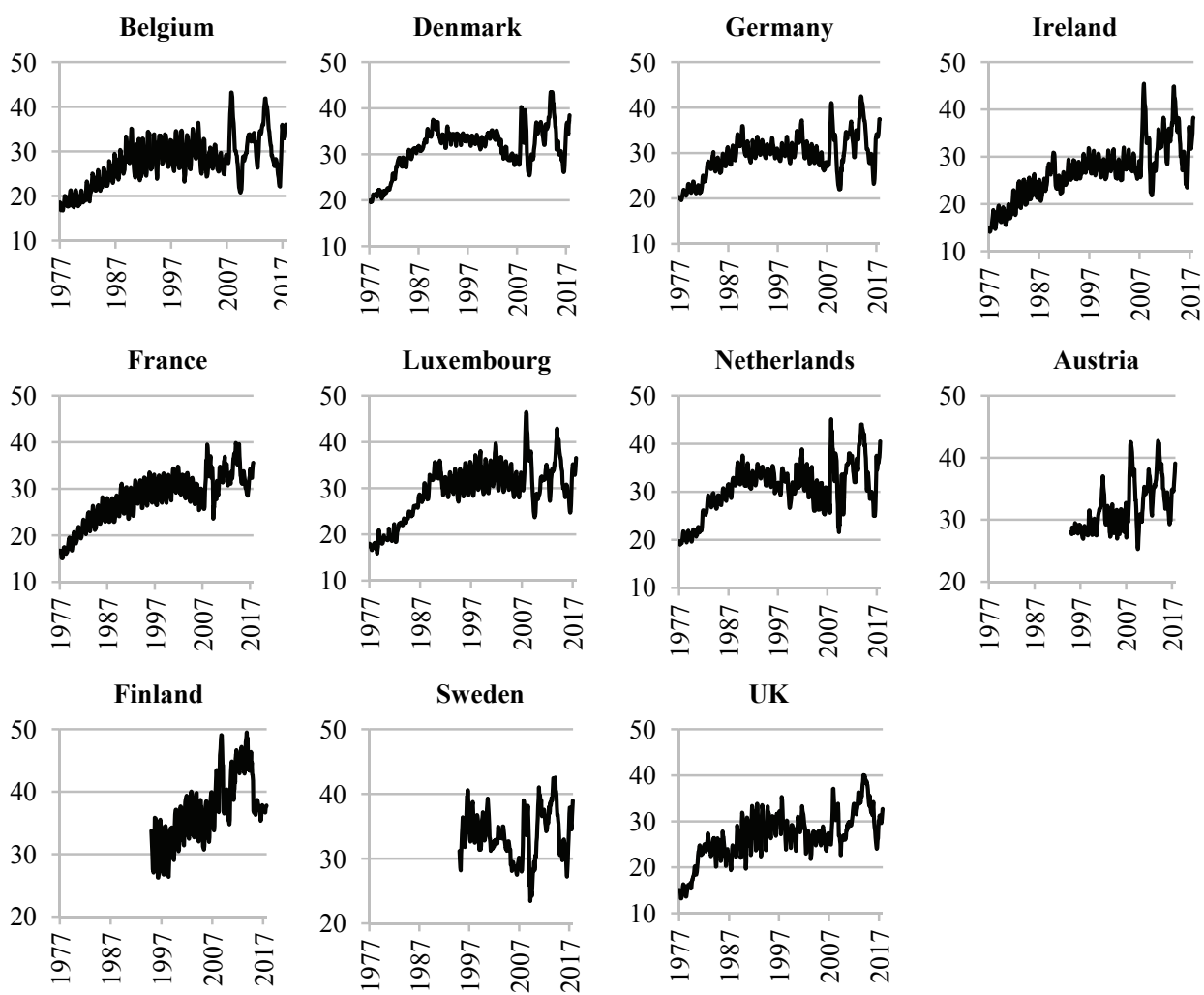

Fig. 2. Farmgate milk prices in selected EU countries (EUR/100 kg)

Source: EU Milk Market Observatory.

Table 1. Descriptive statistics of farmage milk prices in particular EU countries (EUR per $100 \mathrm{~kg}$ )

\begin{tabular}{l|llllll}
\hline Country & Start & End & Min & Mean & Median & Max \\
\hline Belgium & Jan-77 & Sep-17 & 16.76 & 27.76 & 27.78 & 43.20 \\
Denmark & Jan-77 & Sep-17 & 19.62 & 31.32 & 32.33 & 43.50 \\
Germany & Jan-77 & Sep-17 & 19.59 & 29.49 & 29.65 & 42.46 \\
Ireland & Jan-77 & Sep-17 & 14.12 & 26.79 & 26.98 & 45.40 \\
France & Jan-77 & Sep-17 & 15.07 & 28.21 & 28.94 & 39.82 \\
Luxembourg & Jan-77 & Sep-17 & 15.85 & 29.43 & 30.27 & 46.42 \\
Netherlands & Jan-77 & Sep-17 & 18.98 & 30.65 & 31.28 & 45.09 \\
Austria & Jan-95 & Sep-17 & 25.27 & 31.94 & 30.78 & 42.70 \\
Finland & Jan-95 & Sep-17 & 26.27 & 37.18 & 36.87 & 49.50 \\
Sweden & Jan-95 & Sep-17 & 23.48 & 33.71 & 33.39 & 42.52 \\
UK & Jan-77 & Sep-17 & 13.26 & 26.82 & 26.67 & 40.01 \\
\hline Sourc:
\end{tabular}

Source: own calculations. 
According to the literature seasonality amplitude of the farmagate milk prices is not constant over the time and tends to diminish with the development of dairy sector (Szajner, 2014; Iwan, 2005; Matysik-Pejas, 2007). Therefore, in order to address the problem of nearly constant seasonal component which appears in case of decomposition of time series using Kalman filter (Bergmann et al. 2013, 2015; Nicholson and Stephenson, 2015) the multiplicative decomposition of time series was implemented. The same approach was employed by Szajner (2014). In a multiplicative decomposition, the seasonal components change proportionately with the trend. If the trend rises, so do the seasonal effects while if the trend moves downward the seasonal effects decrease too. The multiplicative model can be specified as:

$$
\mathrm{Y}_{t}=\mathrm{C}_{t} * \mathrm{~S}_{t} * \mathrm{I}_{t}
$$

where $Y_{t}$ is the original time series, $C_{t}$ is the trend-cycle, $S_{t}$ is the seasonal component, and $\mathrm{I}_{t}$ is the irregular component. Therefore, despite the fact, that the multiplicative decomposition, contrary to the Kalman filter, does not enable to derive the cyclical component from the time series, it includes them in the trend-cycle component $\mathrm{C}_{t}$. Seasonal adjustment process was conducted using the Census X-12 procedure (U.S. Census Bureau, 2011).

In order to visualize the change in seasonal component obtained time series were converted into annual data using following algorithm:

$$
\mathrm{SF}_{\mathrm{it}}=\left(\frac{1}{\min \left(\mathrm{S}_{1 \mathrm{it}}, \mathrm{S}_{2 \mathrm{it}}, \mathrm{S}_{3 \mathrm{it}}, \ldots, \mathrm{S}_{12 \mathrm{it}}\right)}-\frac{1}{\max \left(\mathrm{S}_{1 \mathrm{it}}, \mathrm{S}_{2 \mathrm{it}}, \mathrm{S}_{3 \mathrm{it}}, \ldots, \mathrm{S}_{12 \mathrm{it}}\right)}\right) * 100
$$

where $S_{j i t}, j \in[1,2,3, \ldots, 12]$ are multiplicative seasonal factors for particular months for $\mathrm{i}$ country and year $t$.

The purpose of the second part of the research is to test the hypothesis that the amplitude of seasonal component in the farmgate milk prices in EU is decreasing together with the growing integration of the EU milk market with the global milk market. The starting point for the analysis and also an endogenous variable are annual time series obtained in the first part of the research $\left(\mathrm{SF}_{\mathrm{it}}\right)$ from the equation 2 . The change in seasonality pattern was modeled using two explanatory variables. The first variable is annual milk deliveries per cow in particular countries (development ${ }_{i t}$ ). Milk deliveries per cow may be treated as a proxy for the development of dairy sector determined by calvings distribution, feeding regime and size of dairy sector. The higher average milk yield is, the dairy sector is more developed. Therefore, an increase in milk deliveries per cow should lead to a decrease in amplitude of seasonal component of farmgate milk price in the EU. Data on the milk deliveries and the size of milk cows herds in particular EU countries are annual data obtained from Eurostat. The second explanatory variable is the average percentage difference between milk prices in particular EU countries and the United States (difference ${ }_{i t}$ ). This variable serves as a proxy for the integration of EU milk market with global milk market. The lower average percentage difference between these prices is, the EU market is more integrated with the global market. According to the hypothesis tested in this part of the research, higher integration of EU milk market with the global milk market should lead to decrease in amplitude of the seasonal component of farmgate milk price in EU. Monthly milk prices for particular EU countries come from the EU Milk Market Observatory and were originally nominated in EUR. In turn, monthly US milk price (all-milk price) was obtained from United States Department of 
Agriculture - National Agricultural Statistics Service and converted into EUR using monthly averages of Thomson Reuters Datastream EUR/ECU vs. USD spot rate. Monthly time series were converted to annual data using annual averages. It may be argued that the farmgate milk price from New Zealand would be a better proxy of global milk market that the US price. Nevertheless, the time series for the US were much longer than for New Zealand. Moreover, it has been proved that the US dairy market is well integrated with the global milk market (Newton, 2016) which allows to treat it as a proxy of the global milk market. Table 2 reports the length of sample for particular countries and descriptive statistics for the variables used in the research.

Table 2. Descriptive statistics of explanatory variables

\begin{tabular}{|c|c|c|c|c|c|c|c|c|c|c|c|}
\hline \multicolumn{12}{|c|}{ Annual milk deliveries per cow $(1,000 \mathrm{~kg})$ - $\left(\right.$ development $\left._{i t}\right)$} \\
\hline & Belgium & Denmark & Germany & Ireland & France & $\begin{array}{c}\text { Luxem } \\
\text { bourg }\end{array}$ & $\begin{array}{c}\text { Netherl } \\
\text { ands }\end{array}$ & Austria & Finland & Sweden & UK \\
\hline Start & 1977 & 1977 & 1977 & 1977 & 1977 & 1977 & 1977 & 1995 & 1995 & 1995 & 1977 \\
\hline End & 2016 & 2016 & 2016 & 2016 & 2016 & 2016 & 2016 & 2016 & 2016 & 2016 & 2016 \\
\hline Min & 2.90 & 4.52 & 3.79 & 2.58 & 2.95 & 3.50 & 4.58 & 3.20 & 5.91 & 6.73 & 4.44 \\
\hline Mean & 4.68 & 6.76 & 5.49 & 4.19 & 5.15 & 5.26 & 6.30 & 4.72 & 7.39 & 7.90 & 5.93 \\
\hline Median & 4.68 & 6.46 & 5.27 & 4.27 & 5.22 & 5.42 & 6.41 & 4.95 & 7.60 & 8.02 & 5.62 \\
\hline Max & 7.58 & 9.33 & 7.53 & 5.19 & 6.98 & 6.97 & 8.10 & 5.78 & 8.68 & 8.71 & 7.97 \\
\hline \multicolumn{12}{|c|}{$\begin{array}{l}\text { Percentage difference between the farmgate milk prices in pa } \\
\left.\text { (difference }{ }_{i t}\right)\end{array}$} \\
\hline & Belgium & Denmark & Germany & Ireland & France & $\begin{array}{c}\text { Luxem } \\
\text { bourg }\end{array}$ & $\begin{array}{c}\text { Netherl } \\
\text { ands }\end{array}$ & Austria & Finland & Sweden & UK \\
\hline Start & 1977 & 1977 & 1977 & 1977 & 1977 & 1977 & 1977 & 1995 & 1995 & 1995 & 1977 \\
\hline End & 2016 & 2016 & 2016 & 2016 & 2016 & 2016 & 2016 & 2016 & 2016 & 2016 & 2016 \\
\hline Min & -10.29 & 4.33 & 4.38 & -22.44 & -6.81 & -9.77 & 2.00 & 19.05 & 27.98 & 15.88 & -17.44 \\
\hline Mean & 35.01 & 42.37 & 39.19 & 32.34 & 35.82 & 37.96 & 41.12 & 39.29 & 47.99 & 41.99 & 32.56 \\
\hline Median & 36.91 & 45.85 & 40.90 & 33.56 & 40.23 & 41.99 & 43.74 & 38.88 & 46.98 & 40.51 & 36.35 \\
\hline Max & 62.23 & 66.64 & 63.68 & 58.72 & 63.68 & 65.82 & 65.20 & 63.88 & 68.50 & 68.18 & 58.55 \\
\hline
\end{tabular}

Source: own calculations.

Data used in the research was obtained over multiple time periods for the same group of countries. Therefore, due to characteristics of data set the second part of the research employs panel regressions. The main advantage of panel models is the opportunity to use data of multiple observations over the same units which allows to estimate more realistic models than in case of a single time series or single cross-sections models (Verbeeck, 2004). Panel data usually provide the researcher with a higher number of degrees of freedom and reduce the collinearity among explanatory variables, hence improving the efficiency of econometric estimates (Hsiao, 2003, Baltagi, 2005).

Panel data have a cross-sectional dimension $N$ and a time-series dimension $T$. Therefore, in the panel models variables are indexed by an $i$ for the individuals $(i=$ $1, \ldots, N)$ and by a $t$ for the time periods $(t=1, \ldots, T)$. In the general form panel models can be specified as: 


$$
y_{i t}=\alpha+X_{i t}^{\prime} \beta+u_{i t}
$$

where $\alpha$ is a scalar, $X_{i t}$ is the $i$ th observation on $\mathrm{K}$ explanatory variables and $\beta$ defines $\mathrm{K} \mathrm{x}$ 1 vector of explanatory variables. Error component $u_{i t}$ can be written as:

$$
u_{i t}=\mu_{i}+v_{i t}
$$

where $\mu_{i}$ is the unobservable individual-specific effect and $v_{i t}$ denotes the remainder disturbance (Baltagi, 2005). Research employs the following sorts of panel models: random effects model and fixed effects model. In random effects models the individual-specific effects $\mu_{\mathrm{i}}$ are random variables with mean 0 and variance $\sigma_{\mu}^{2}$. Therefore, an assumption that $\mu_{i}$ are random variables in random effects models enable to avoid the loss of degrees of freedom. Random effects models are estimated usually by generalized least squares (GLS) method. The main feature of fixed effects model is that $\mu_{i}$ are assumed to be estimated fixed parameters. $\mu_{i}$ captures characteristics associated with particular individuals which are constant over time, so called "fixed effects". Remainder disturbance $v_{i t}$ is assumed to be independent and identically distributed with mean 0 and variance $\sigma_{v}^{2} . X_{i t}$ are assumed to be independent of the $v_{i t}$ for all $t$ and $i$. Fixed effects models are estimated usually by ordinary least squares (OLS) method.

\section{Results}

Figure 3 shows seasonal components of analyzed farmgate milk prices while Figure 4 presents their conversion to the annual data using algorithm presented in the equation 2 . The results indicate that the seasonality remains an important factor determining the farmgate milk prices in EU although it is not such explicit as before 2007. It supports the view that due to the biological nature of milk production the seasonality cannot be completely eliminated from its price. Nevertheless, the significance of the seasonality in determining farmagate milk prices has markedly diminished after 2007 in most analyzed countries.

The estimation of panel regression, which was the second part of the research, provides useful information about the causes of diminishing seasonality amplitudes of the farmgate milk prices in EU. The final model is specified as in Table 3.
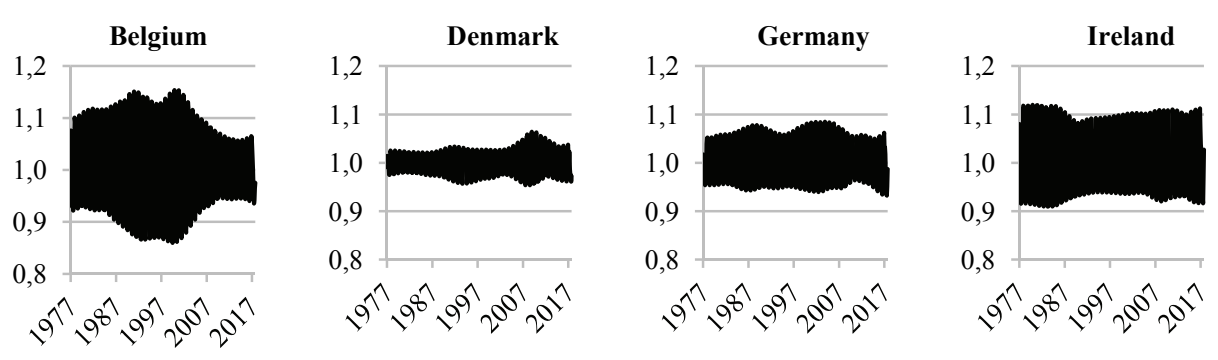

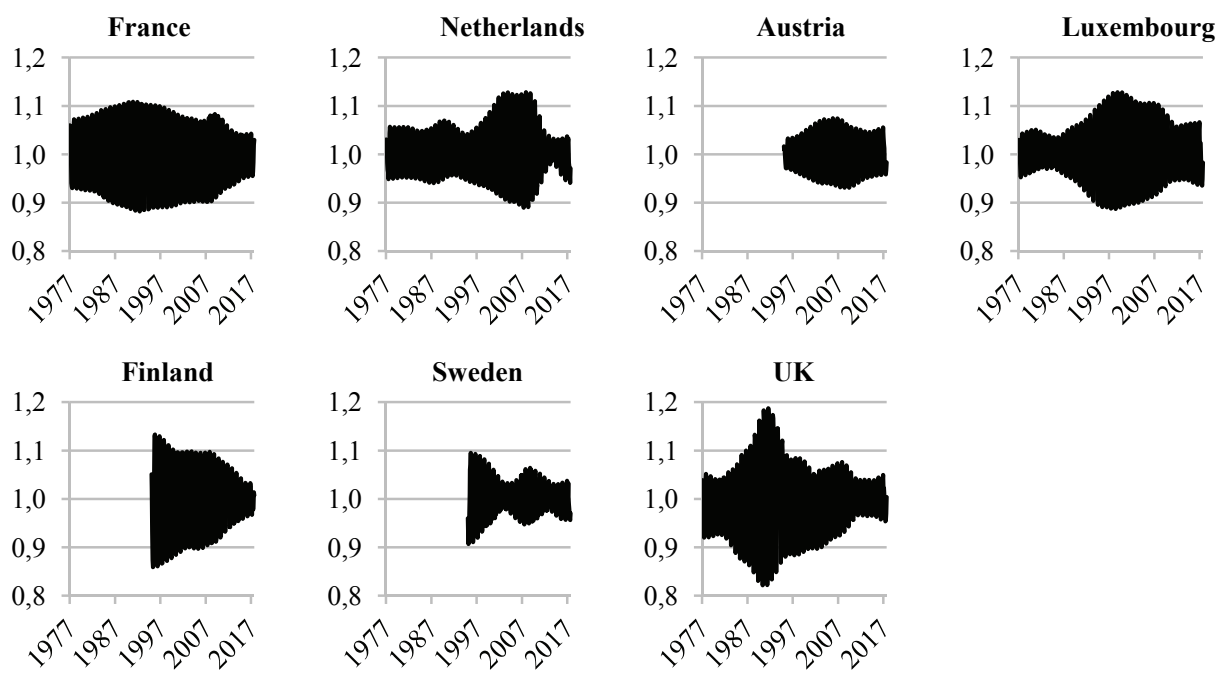

Fig. 3. Seasonal components of farmgate milk prices (pts) Source: own calculations.
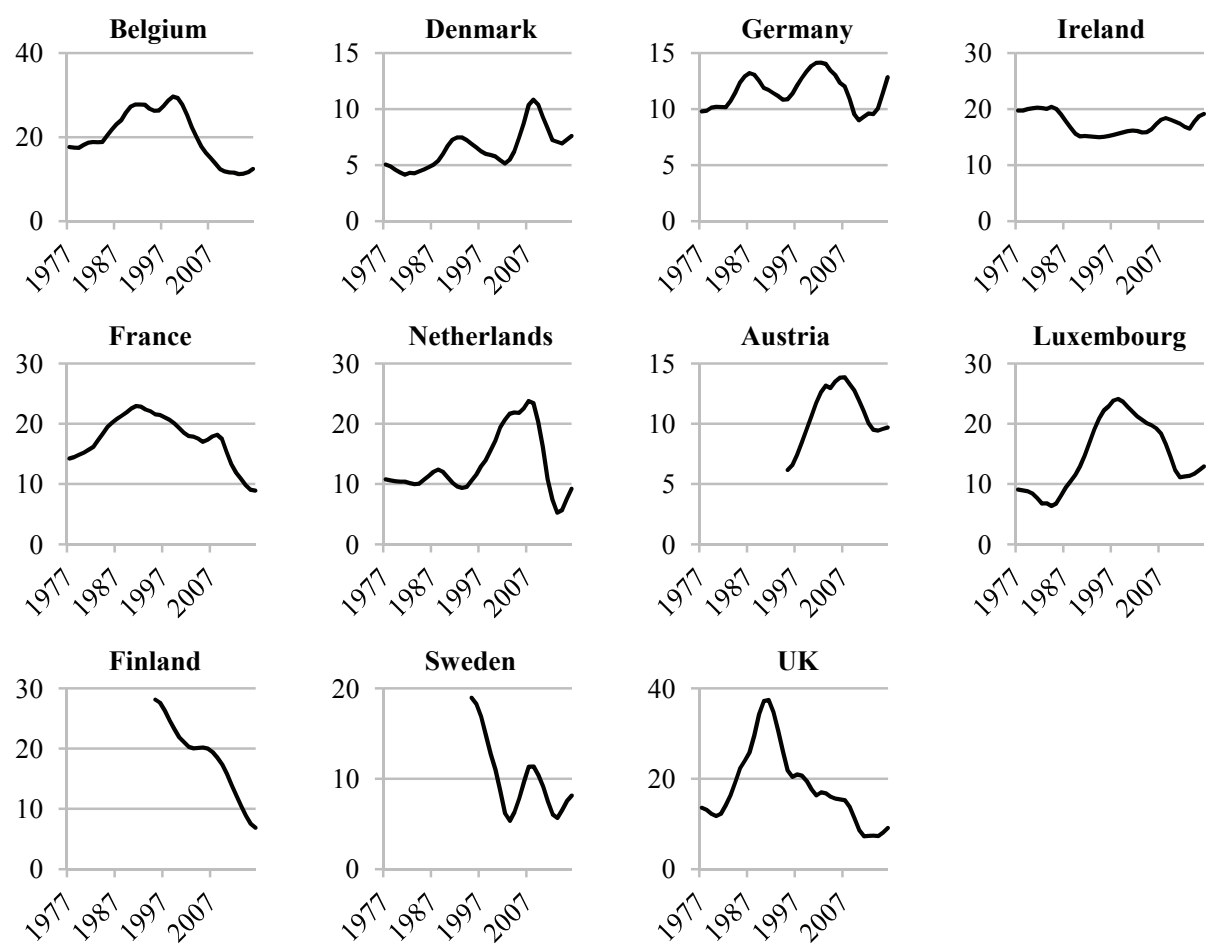

Fig. 4. Annual seasonal components of farmgate milk prices - variable $\left(\mathrm{SF}_{\mathrm{it}}\right)$

Source: own calculations.

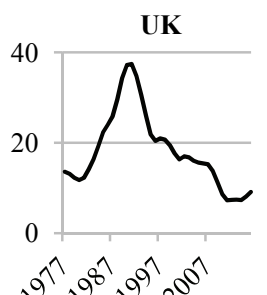


Table 3. Panel model specification. Endogenous variable is $\mathrm{SF}_{\mathrm{it}}$

\begin{tabular}{l|llll}
\hline Variable & Coefficient & Std. Error & t-Statistc & P-value \\
\hline Intercept & 15.125 & 1.782 & 8.489 & $0.000^{* * *}$ \\
Development $_{i t}$ & -0.692 & 0.213 & -3.251 & $0.001^{* *}$ \\
Difference $_{i t}$ & 0.086 & 0.013 & 6.767 & $0.000^{* * *}$ \\
\hline
\end{tabular}

Source: own calculations.

All explanatory variables are statistically significant. R-squared amounted to 0.11 indicating on the moderate goodness of fit, as far as panel data considered. According to the results of the estimation an increase in milk productivity by $1,000 \mathrm{~kg}$ per cow (Development ${ }_{i t}$ ) leads ceteris paribus to decrease in seasonality amplitude by $0.69 \mathrm{pp}$. With regards to percentage difference between farmgate milk prices in particular EU countries and the US (Difference ${ }_{i t}$ ), its decrease by $1 \mathrm{pp}$. leads ceteris paribus to a drop in seasonality amplitude by $0.09 \mathrm{pp}$.

Hausman test indicates that random effects specification is more suitable than fixed effects. It most likely reflects that nowadays country specific factors like the climate conditions are less important. The choice of the random effects specification was also confirmed by the results of Breusch-Pagan Lagrange multiplier test. BreuschGodfrey/Wooldridge and Breusch-Pagan tests indicated on autocorrelation and homoscedasticity in the model. Therefore, addressing that problem White's robust estimators of the covariance matrix were used (White, 1980).

\section{Conclusions}

The purpose of the research was to test the hypothesis that the seasonality still plays an important role in shaping the farmgate milk prices in EU. It also investigated if the growing integration of the EU milk market with the global milk market leads to decrease in amplitude of the seasonal component in EU farmgate milk prices. The results confirm that seasonality remains a significant factor determining farmgate milk prices in EU although its role has markedly diminished after 2007 in most analyzed countries. Moreover, the results suggests that it is connected not only with the development of EU dairy sector, which is consistent with the results of Szajner (2014), Iwan (2005) and Matysik-Pejas (2007), but also with its growing integration with the global milk market. Therefore, it can be expected that in the future, together with the further globalization of the milk market, the significance of the seasonality in determining farmgate milk prices in EU will be diminishing. As a consequence, findings from this research have implications for the forecasting of milk prices in EU. Moreover, the results from this study may be used in the further research on how globalization affects the role of local factors in determining the price transmission in agricultural markets.

\section{References}

Allore, H.G., Oltenacu, P.A., Erb, H.N. (1997). Effects of season, herd size, and geographic region on the composition and quality of milk in the northeast. Journal of Dairy Science 80, 3040-3049. 
Auldist, M.J., Walsh, B.J., Thomson, N.A. (1998). Seasonal and lactation influences on bovine milk composition in New Zealand. Journal of Dairy Research 65, 401-411.

Baltagi, B.H. (2005). Econometric Analysis of Panel Data, John Wiley \& Sons, Chichester, Chapters 1-2.

Baul, S., Cziszter, L., Acatincai, S., Gavojdian, D., Erina, S., Marcu, A., Buzamat, G., George R.G. (2014). Seasonal Influences on Milk Yield and Composition Dynamics during a Normal Lactation in Dairy Cows: Milk Yield, Fat and Protein Precentage. Scientific Papers Animal Science and Biotechnologies 47(1), 260-265.

Bergmann, D., O’Connor, D., Thümmel, A. (2013). A decomposition analysis of the EU farm gate milk price, Paper prepared for presentation at the 87th Annual Conference of the Agricultural Economics Society, April 8-10, 2013, University of Warwick, United Kingdom

Bergmann, D., O'Connor, D., Thümmel,A. (2015). Seasonal and cyclical behaviour of farm gate milk prices. British Food Journal 117(12), 2899-2913.

Burke, F., Murphy, J.J., O'Donovan, M., O’Mara, F.P., Kavanagh, S., Mulligan, F.J. (2007). Comparative Evaluation of Alternative Forages to Grass Silage in the Diet of Early Lactation Dairy Cows. Journal of Dairy Science 90, 908-917.

Dooley, A.E. (2002). Milk segregation on dairy farms. Ph.D. Thesis, Massey University, New Zealand.

Elgersma, A., Ellen, G., van der Horst, H., Boer, H., Dekker, P.R., Tamminga, S. (2004). Quick changes in milk fat composition from cows after transition from fresh grass to a silage diet. Animal Feed Science and Technology 117, 13-27.

Hayer, S.S, Jefferson, A.R.S., Dietrich, D. (2019). Vertical coordination in the Brazilian milk supply chain: the case of 3B Agro LTDA. International Food and Agribusiness Management Review, 22(3), 435-449.

Hsiao, C. (2003). Analysis of Panel Data, Cambridge University Press, Cambridge, Chapters 1-3

Iwan, B. (2005). Sezonowość skupu mleka. Roczniki Naukowe Stowarzyszenia Ekonomistów Rolnictwa $i$ Agrobiznesu 7(2), 79-83.

Kelly, A.L. (2001). Primary milk production. In: T.Y Adnam, B. A. Law: Mechanization and Automation in Dairy Technology, Sheffield Acad. Press, Sheffield, 40-47.

Killen, L., Keane, M. (1978). A Linear Programming Model of Seasonality in Milk Production. Journal of the Operational Research Society 29(7), 625-631.

Matysik-Pejas, R. (2007). Seasonality of milk purchase and milk purchase prices before and after introducing the quota system in Poland. Problems of World Agriculture, 17(2), 258-266.

Nateghi L., Morvarid, Y., Elham, Z., Gholamian, M., Mohammadzadeh, M. (2014). The effect of different seasons on the milk quality. European Journal of Experimental Biology 4(1), 550-552.

Newton, J. (2016). Price Transmission in Global Dairy Markets. International Food and Agribusiness Management Review 19, 57-72.

Nicholson, Ch.F., Stephenson, M.W. (2015). Milk Price Cycles in the U.S. Dairy Supply Chain and Their Management Implications. Agribusiness 31, 507-520.

Oldemiro, A.R., Cabrita, A.R.J., Rosa, H.J.D., Alves, S.P., Duarte, V., Fonseca, A.J.M., Vouzela, C.F.M., Pires, F.R., Bessa, R.J.B. (2016). Changes in milk production and milk fatty acid composition of cows switched from pasture to a total mixed ration diet and back to pasture. Italian Journal of Animal Science 15(1), 76-86.

Scott, T.A., Yandell, B., Zepeda, L., Shaver R.D., Smith, T.R. (1996). Use of Lactation Curves for Analysis of Milk Production Data. Journal of Dairy Science 79(10), 1885-1894.

Sienkiewicz, J., Góralska, M. (2009). Zmiany w zawartości tłuszczy w mleku krowim na przestrzeni roku. Zeszyty Naukowe Ostrołeckiego Towarzystwa Naukowego 23, 185-196.

Szajner, P. (2014). Seasonal Fluctuations on Dairy Market in Poland and UE-15. Problems of World Agriculture 14(1), 120-129

U.S. Census Bureau (2011). X-12-ARIMA Reference Manual, U.S. Census Bureau, Washington DC

Verbeek, M. (2004). A Guide to Modern Econometrics, John Wiley \& Sons, Hoboken, Chapter 10.

White, H. (1980). A Heteroskedasticity-Consistent Covariance Matrix Estimator and a Direct Test for Heteroskedasticity. Economterica 48(4), 817-838.

\section{For citation:}

Olipra J. (2019). Change in Seasonality Pattern of EU Farmgate Milk Price. Problems of World Agriculture, 19(3), 75-84; DOI: 10.22630/PRS.2019.19.3.48 